\title{
CYRENAICA: CULTURE AND ANTIQUITIES
}

$0^{\mathrm{N}}$ NCE more with the fall of Benghazi and the British occupation of Cyrenaica, the Libyan menace to Egypt is frustrated. For, indeed, the present campaign against the forces of Italy in her North African colonies is but the latest phase in a conflict between the peoples of the Valley of the Nile and the dwellers in the Libyan Desert and on the coastal fringe westward from Egypt, which mutatis mutandis has endured intermittently for many a hundred years. So long ago as the thirteenth century B.c., when the Nineteenth Dynasty ruled over Egypt, Pharaoh Menephthah drove back from the Delta the attack of the peoples of the Mediterranean Sea, Achæans and Lycians, Sardinians and Tyrsenians as they are thought to have been, who, in alliance with and under the leadership of Libyan chiefs, sought to overrun the rieh lands of the Nile. But such acts of aggression were not entirely one-sided. Long before, under the Twelfth Dynasty, Amenemhat I had sought to extend his empire over Libyan tribes with the object of exacting tribute from the wealth acquired by their control of the caravan routes from the interior. Under the Twenty-second Dynasty the Libyans with Sheshonq, the Shishak of the Bible who besieged Jerusalem, as their first ruler, established a hold over Egypt which endured from 950 until 740 B.C.

That campaigning in Libya in those days was no less strenuous than it was found to be by the British Imperial troops is suggested by the story of the rise to power of Amasis in 572 B.C. His army, when sent on an expedition into Libya, was convinced that it was intended that they should all perish. They rebelled and raised Amasis to the supreme power, displacing Hophra, the ruling monarch.

Since the Italian occupation, the term 'Libya' has been applied to the two provinces of Tripolitania and Cyrenaica. In the latter, the eastern province of Cyrenaica, geographical conditions, which have been made in some measure generally familiar by recent events, have had a marked effect on the history and development of culture of the inhabitants. The dominant features are two great plateaux which rise steeply from a narrow coastal strip, and then slope down to the desert, which the more important, Jebel Akhdar, reaches at a distance of some eighty miles. Its heights are well watered with abundant springs and its good red soil grows good crops of barley, while the AraboBerber nomad or semi-nomad tribesmen find here pasture for their herds of cattle, sheep and camels.

Little less important in a cultural context is the Augila depression, which runs by a remarkable series of oases from the Gulf of Sidra, the ancient Syrtes, to the regions of the Upper Nile. It has served as a line of communication and path of cultural diffusion for countless ages; but in recent years its importance as a line of communication with the interior has declined with the opening of the Khartum Railway. Of the oases traversed, Kufra, a group of five at the head of the Libyan Desert, covering some 7,000 square miles, is the most important; it is best known, perhaps, on account of the Senussi sect of Moslems, founded in the nineteenth century, who had their headquarters here until in 1928 the Italians occupied the interior, driving them back to the oasis of Jaghbub then recently ceded from Egypt. Of special interest to archæologists is the "lost" oasis of Oueinat, reached by A. M. Hassanein Bey in 1923, where were discovered some remarkable series of rock paintings and drawings which have since been the subject of considerable study and speculation.

The modern indigenous population of Cyrenaica, since the Arab conquest of A.D. 641, is AraboBerber, an amalgam in which the Berber tongue has virtually disappeared along with the script which, as inscriptions show, had been evolved but now survives only among the Masked Tuareg of the western Sahara. Physically, the population belongs mainly to the North African type of the Mediterranean race. Indeed, among the theories of derivation of the North African Berber as found farther to the west, one would assign them to an origin in Libya. In their origins the people of Libya would appear basically to have been closely akin to the proto- or pre-dynastic Egyptians, if reliance is to be placed upon the scanty human skeletal remains which have been found and examined, notably at Mersa Matruh.

Archæological evidence may well be regarded as bearing out a close relation with Egypt in early times. Finds of palæoliths of Mousterian type similar to those of Egypt would seem to confirm this view. On the other hand, more intensive exploration and study, such as the Stone Age has received in French North Africa and has been given by Miss Caton-Thompson to the Stone Age cultures of Khargeh, may reveal links by which Libya will be joined in a North African palæolithic complex. In the meantime, for later ages from 
mesolithic times onward, detailed study of the Oueinat pictographs has not only revealed evidence of a cultural, even possibly a racial, sequence, but also in conjunction with other evidence the possibility of a connexion with north-west Africa, going back to neolithic or even mesolithic times, and of a diffusion of culture from the upper regions of the Nile which must have traversed Libya by the desert-oasis route and cannot fail to have had its cultural effect on the way.

Up to the middle of the nineteenth century, knowledge of Cyrene and the Pentapolis was confined almost exclusively to literary sources. From Herodotus, we learned of its foundation by Battos, its first ruler, as a colony from Therae, in accordance with the behest of the Delphic oracle, after a misunderstanding of the instruction that it should stand "between the waters" had led to an abortive settlement on the island of Plataea in the Gulf of Bomba. This took place in the middle of the seventh century B.C. The city, which was then built on the high ground in the midst of springs, and appropriately and of right was dedicated to Phœbus Apollo, grew to be the greatest of Greek colonies, with Apollonia as its port, after it adopted a constitution framed by Demonax of Mantinea. This constitution divided the people into three tribes and determined the hostility between Greeks and Libyans, which had previously prevailed and which the intervention of Amasis for the Libyans had failed to compose.

The foundation of Cyrene was followed first by that of Barca, then of Hesperides-Berenice (Benghazi) and Arsinoe, with Apollonia making up the five cities of the Pentapolis. Derna (DarnisZarine) was a later Ptolemaic foundation. Cyrene, after a period of great prosperity due to commerce, in which at one time the city attained a population of 100,000 , was the home of the Cyrenaic post-Socratic school of philosophy: it declined under the Ptolemies, to whom it had fallen as a result of its submission to Alexander in 331 B.c. Trade between Egypt and Carthage, upon which its prosperity had largely depended, was then diverted to the more direct route through Barca. Towards the close of the Ptolemaic rule, Apian gave Cyrenaica to Rome by his will and, with Crete, it was formed into a Roman province. It now had a large Jewish population, but disorders among them in both Barca and Cyrene under Hadrian brought about a complete eclipse in favour of Apollonia in A.D. 115-16. The two cities revived under Arab rule and for some time thrived on the trade between Alexandria and Qairwan, to fall with the remainder of the province into obscurity and disorder when the Ottoman Turks came into power.

In certain respects the fate of Cyrene and its decline under the Ptolemies and its later Roman masters was a piece of good fortune for posterity. Alone among archæological sites of Greek origin of any importance in Roman North Africa, it preserves its early form virtually untouched by Roman magnificence. The state of preservation of the temenos, or sacred enclosure, is unique. Here two baths only were introduced by the Romans. Nothing was known of the antiquities of Cyrene until it was visited in 1861 by two English officers on leave from Malta, R. Murdock Smith and E. A. Porcher, by whom the dedicatory temple of Apollo was identified and a number of antiquities retrieved which were afterwards sent to the British Museum. The next exploration of any note was by an American expedition, and was directed to the excavation of the Acropolis. This began in 1910 but ceased when Cyrenaica was taken over by the Italians in 1912. Since then, excavations have been carried out more or less systematically by the Italians, and with some enthusiasm since 1928, when the Fascist colonial policy in Africa had assumed more highly colourful aims in the revival of the glories of the Roman Empire. The archæological finds from the excavations at Cyrene are deposited in the Museum at Benghazi, with the exception of the Aphrodite Anadyomene, which is in Rome.

The original foundation of the acropolis of Cyrene stands on the western of two hills. In the valley between them and climbing the southwestern slopes of the eastern hill lies the town. The acropolis is surrounded by a wall. Outside on the north is the sanctuary of Apollo, below the sacred fountain Kyra. This spring issues through a portico from a tunnel artificially enlarged. Its course upward can be followed for three to four hundred yards, the walls being freely inscribed by visitors. The sacred precinct presents a new feature in Roman Africa, in that the underlying Greek plan can be readily followed. In it are the temples of Artemis and Apollo, each with a large altar standing before it. That before the temple of Apollo is twenty-three yards long. A remarkable feature of the temple of Artemis is a Nymphæum, which possibly may have been used for purificatory rites. In the floor of the temple of Apollo treasure cists have been found. The original temple erected by Battos I was reconstructed under Augustus, and a further reconstruction was carried out under (possibly) Hadrian, but the original plan is still to be discerned. Subsidiary temples, a Greek theatre, and Roman baths are within the temenos walls, which are entered by Roman propylæa. Some twenty marble statues have been brought to light on this part of the site. Among the more remarkable finds from the eastern hill is a fine head of Zeus of Pheidian type, showing a trace 
of gilding, to which a head of Poseidon forms a pendant.

A striking feature of the plan of the site is the Sacred Way, which lead from the sanctuary past the sacred fountain to the Agora. This latter is a colonnaded area of the conventional Roman type, with its capitol and official buildings. Here, however, are also survivals from the Greek period, the Heroon and the tomb of Battos.

To most of those, however, who have visited ancient Cyrene, the most impressive spectacle has been the vast array of tombs which line the Sacred
Way along the road from Cyrene to Apollonia, They vary in size and dignity from the simple cist. with its slab cover, to the elaborate and stately façade which admits to one or more halls or chambers in which the burials lie in pits in the floor and in recesses. A few wall paintings survive, for the most part representing some form of funeral games. Participants, all in Greek dress, are both black and white in colour. Presumably, therefore, as under the constitution of Demonax in civic matters, so in ritual, Greeks and indigenes ignored the colour line.

\section{RICKETS, CALCIUM AND CEREALS}

$\mathrm{T}^{\mathrm{H}}$ HAT consumption of cereals may in certain circumstances lead to the appearance of rickets was first shown in 1920, when E. Mellanby ${ }^{1}$ found that increasing the amount of them in the diet of young animals that were deficient in the antirachitic vitamin increased the intensity of rickets. Mellanby at first supposed that cereals increased the rate of growth of animals, and therefore increased the demand for the food factors necessary for the calcification of the bones and teeth. But his later experiments showed that cereals could be graded in their rachitogenic effect, oatmeal being very potent, and wholemeal wheat flour being more rachitogenic than white flour; yet the cereals with the largest amount of calcium and phosphorus, such as oatmeal and wholemeal flour, tended to cause the lowest retention of these elements in the bones and teeth. Mellanby supposed that these cereals contained an active rachitogenic substance, and this view was strengthened by his observation ${ }^{2}$ that the effect could be destroyed by boiling the cereal with dilute hydrochloric acid. He further showed that the rachitogenic effect of cereals could be completely antagonized by adding sufficient vitamin $\mathrm{D}$ to the diet, and that it could be largely antagonized by adding calcium carbonate or phosphate.

In the course of her experiments on diet and the teeth, M. Mellanby ${ }^{3}$ showed that germination of oats did not affect their anticalcifying action, but this action was greatly diminished if they were ground and allowed to stand for two days. She considered that the destruction might be due to enzyme changes or to the production of vitamin D. Templin and Steenbock ${ }^{4}$, however, found that the disappearance of the rachitogenic action of maize, when it was germinated and autolysed, was accompanied by a change of its organic phosphorus to the inorganic form. Steenbock et al. ${ }^{5}$ had previously suggested that inorganic phosphorus added to the diet might not be equivalent in physiological properties to the organic phosphorus in cereals; their experiments certainly demonstrate the fact that inequality of phosphorus intake is not the sole reason for the difference in calcifying action of the various cereals.

Steenbock's suggestion that the phosphorus compounds of cereals differ in their biological availability was followed up by Bruce and Callow ${ }^{6}$. Most cereals are rich in phosphorus, but $50-80$ per cent is present in the form of phytin-phosphorus, phytin being the calcium-magnesium salt of phytic acid (inositolhexaphosphoric acid). Using rats on diets high in calcium and low in phosphorus and vitamin $\mathrm{D}$, Bruce and Callow showed that the rachitogenic effect of cereals could be explained by the low availability of phytic acid phosphorus. This form of phosphorus was also shown to be comparatively unavailable to man (McCance and Widdowson ${ }^{7}$ ). Bruce and Callow further stated that when deficiency of calcium was the factor limiting calcification, there were grounds for believing that excess of phytic acid would interfere with the absorption of calcium ; and Starkenstein ${ }^{8}$ had shown that calcium phytate was insoluble or non-ionized. Mottram and Palmer ${ }^{9}$ concluded that the rachitogenic action of cereals is not specific, but is due to their unbalanced calciumphosphorus ratio. But the more extensive work of Lowe and Steenbock ${ }^{10}$ had shown that not only the ratio of calcium to phosphorus, but also the proportion of the latter present in the phytin of cereal, determined its rachitogenic potency ; they found that phytin phosphorus was partially available to the rat when the diet was low in calcium, but that the addition of calcium carbonate made it almost completely unavailable. 